\author{
O. Є. СІЧKOPI3
}

\title{
ГОЛОВНІ АСПЕКТИ ПІДГОТОВКИ СІМЕЙНОГО ЛІКАРЯ В УКРАЇНІ
}

\author{
Львівський національний медичний університет імені Данила Галицького, м. Львів, Україна
}

\begin{abstract}
Мета: аналіз проблеми та перспективи підготовки сімейних лікарів на післядипломному етапі.
Матеріали і методи. Чинні законодавчі акти проаналізовані за принципом структурно-логічного аналізу.

Результати. Основною метою інтернатури за спеціальністю «Загальна практика - сімейна медицина» $\epsilon$ формування професійної компетентності для забезпечення готовності лікарів-інтернів до самостійної роботи як лікаря-спеціаліста. Інтернатура проводиться у фрормі очно-заочного навчання на кафедрах вищих медичних навчальних закладів і закладів післядипломної освіти та практичного стажування в базових установах охорони здоров'я. Заочне стажування для лікарів-інтернів за спеціальністю «Загальна практика - сімейна медицина» повинно здійснюватись на базі первинної медико-санітарної допомоги та амбулаторій сімейного лікаря.

Навчальний план та програма інтернатури розраховані на 2 роки. Протягом першого року - 6 місяців навчання на відповідних кафедрах вищих медичних навчальних закладів, 5 місяців - робота на базі первинної медикосанітарної допомоги та амбулаторій сімейного лікаря, один місяць - відпустка. Протягом другого року - 4 місяці навчання на відповідних кафедрах вищих медичних навчальних закладів, 7 місяців - робота на базі первинної медико-санітарної допомоги та амбулаторій сімейного лікаря, один місяць - відпустка.

Підготовку сімейного лікаря необхідно починати з додипломної освіти з викладанням основ пропедевтики за синдромологічним підходом та специфічного клінічного мислення з орієнтацією на загальну практику - сімейну медицину.

Висновки. Тривалість навчання в інтернатурі з сімейної медицини повинна відповідати рекомендованим термінам міжнародних професійних організацій: WONCA, EURACT, UEMO тощо і тривати не менше 3 років. Заочне навчання має передбачати обов'язкове стажування тривалістю 1-3 місяці в тому закладі, куди скеровані майбутні спеціалісти відповідно до державного розподілу.
\end{abstract}

КЛЮчОВІ СЛОВА: сімейний лікар; підготовка; первинна медико-санітарна допомога.

Кращі показники стану здоров'я і смертності населення сьогодні напряму залежать від підготовки сімейних лікарів, які $€$ базовим елементом первинної медико-санітарної допомоги (ПМСД). Незважаючи на створене правове підґрунтя для розвитку первинної медико-санітарної допомоги на засадах загальної (сімейної) практики, укомплектованість висококваліфрікованими фрахівцями - сімейними лікарями в медичних закладах сьогодні складає 65 \%. Лише 63,8 \% населення України, які уклали угоду з сімейним лікарем, задоволені рівнем медичного обслуговування.

Застосовуючи новітні технології та інноваційні форми навчання ми прагнемо забезпечити високоякісною підготовкою сімейних лікарів. Так у Львівському національному медичному університеті імені Данила Галицького, завдяки створенню імітаційного центру з необхідними манекенами та фантомами, відпрацювання практичних навичок до автоматизму є особливо важливим елементом навчального процесу 3 надання першої невідкладної медичної допомоги.

3 досвіду роботи пропонуємо зміни у підходах до підготовки медичних кадрів первинної ланки, збільшенні термінів навчання на циклах

(C) О. Є. Січкоріз, 2018 інтернатури та спеціалізації з сімейної медицини за міжнародними стандартами, зокрема на заочному етапі навчання.

Враховуючи реальні потреби населення Кабінетом Міністрів України було прийнято розпорядження Про схвалення Концепції Загальнодержавної програми «Здоров'я 2020: український вимір» від 31 жовтня 2011 р. № 1164-р.

Основними завданнями у вищевказаній Концепції зазначено, що збереження та зміцнення здоров'я є її основною метою, на яку впливає зниження показників захворюваності та смертності, а це можливо лише при наданні оперативної, якісної та ефрективної медичної допомоги населенню. Особливу увагу приділяють підготовці фрахівців первинної ланки, а саме підготовці сімейних лікарів.

На сьогодні немає сумніву в тому, що реформування первинної медико-санітарної допомоги на засадах загальної сімейної практики є одним із критеріїв європейського вибору України. Базовим елементом ПМСД є сімейний лікар, який своїми професійними діями повинен позитивно впливати на стан здоров'я населення.

Нові законодавчі акти, які нещодавно прийняті в Україні, а це, в першу чергу, Закон України «Про внесення змін до Основ законодавства України 
про охорону здоров'я щодо удосконалення надання медичної допомоги», створили необхідне правове підґрунтя для розвитку первинної медико-санітарної допомоги на засадах загальної (сімейної) практики. 17 січня 2012 р. МОЗ України затвердило навчальний план та уніфіковану програму циклу спеціалізації за фрахом «Загальна практика - сімейна медицина», яка впроваджена в усіх вищих медичних навчальних закладах освіти. Функціонують і мають уже певний досвід роботи первинні центри сімейної медицини, де надання медичної допомоги на первинному рівні здійснюють не лише сімейні лікарі, але й терапевти та педіатри. Таким чином, розробляються програми розвитку сімейної медицини на перспективу, розширюється база підготовки лікарів загальної практики - сімейної медицини у системі до- та післядипломної освіти. Однак, незважаючи на всі зусилля держави, укомплектованість висококваліфікованими фахівцями - сімейними лікарями в медичних закладах складає 65 \%, ми спостерігаємо зниження статусу та популярності профресії - сімейний лікар серед медичної спільноти, нерозуміння і неприйняття нового фраху серед підготовлених у такий спосіб сімейних лікарів. За даними соціологічного опитування, лише 63,8 \% населення України, які уклали угоду 3 сімейним лікарем, задоволені рівнем медичного обслуговування.

Зрозуміло, що вищі медичні навчальні заклади докладають усіх можливих зусиль для забезпечення високоякісної підготовки сімейних лікарів, застосовуючи для цього новітні технології та форми навчання, такі, як безперервний професійний розвиток фахівців у сорері охорони здоров'я (затверджений Постановою Кабінету Міністрів від 28.03.2018 р. № 302), навчання на робочому місці, крім того, залучаючи нові форми дистанційного навчання, щомісячні семінари-тренінги. Це зумовлено тим, що підготовка сімейних лікарів високої кваліфікації $€$ основним завданням освіти в сучасних умовах реформування практичної охорони здоров'я.

Разом із тим, аналізуючи літературні джерела [1-6], робимо висновок, що післядипломна підготовка фрахівців із сімейної медицини висвітлена недостатньо, є неоднозначною та викликає багато дискусій.

Мета дослідження: аналіз проблеми та перспективи підготовки сімейних лікарів на післядипломному етапі.

Матеріали і методи. Чинні законодавчі акти проаналізовані за принципом структурно-логічного аналізу.

Результати дослідження та їх обговорення. Підготовка лікарів загальної практики складається $з$ двох взаємопов'язаних етапів - додипломної та післядипломної освіти. Післядипломна освіта - це підготовка інтернів на етапі первинної спеціалізації та перепідготовка колишніх терапевтів, педіатрів та інших спеціалістів [2].

Навчальна програма додипломної освіти, затверджена Міністерством охорони здоров'я України у 2015 р., розрахована на два роки: один рік очного навчання (50 \% навчальних годин) на кафредрах і клініках вищих медичних навчальних закладів (ВМН3) та один рік заочного навчання (50\% навчальних годин) - на базах стажування. На сьогодні здобути фрах «Загальна практика - сімейна медицина» можливо лише двома шляхами: через первинну (інтернатуру) або вторинну спеціалізації (проходження навчання на циклі спеціалізації). Наказ МО3 України від 12.06.1993 р. № 148 «Про спеціалізацію (інтернатуру) випускників вищих медичних і фармацевтичних вищих навчальних закладів» регламентував навчання в інтернатурі за фрахом «Загальна практика - сімейна медицина» тривалістю три роки. Однак економічна криза 1994-1995 р. змусила скоротити видатки щодо державного фрінансування всіх галузей, особливо це зачепило освітню та медичну галузі. Тому Міністерство охорони здоров'я прийняло наказ від 06.03.1996 р. № 50 «Про затвердження Переліку спеціальностей та строки навчання в інтернатурі випускників медичних і фармацевтичних вищих навчальних закладів» (зареєстровано в Міністерстві юстиції від 20.03.1996 р. № 134/1159), де тривалість навчання в інтернатурі за фрахом «Загальна практика - сімейна медицина» була зменшена до двох років. Відповідно до типових навчальних планів і програм із цього фраху навчальний час розподілений був за таким принципом: 50 \% - навчання на кафедрах (очний цикл) і $50 \%$ - навчання на базі (заочний цикл). Слід зазначити, що запровадження складання ліцензійного іспиту «Крок-3. Загальна лікарська підготовка» зумовлює виділення певної частини навчального часу з очного блоку навчання на профрільній кафедрі для підготовки до іспиту, тим самим зменшивши кількість навчального часу, який лікарі-інтерни проводять у вищих медичних навчальних закладах, що опосередковано може впливати на якість підготовки висококваліфікованих лікарів із фраху «Загальна практика - сімейна медицина».

щодо проблем вторинної спеціалізації, то наказ МО3 України від 07.12.1998 р. № 346 «Про затвердження Переліку назв циклів спеціалізації та вдосконалення лікарів і провізорів у вищих медичних (фрармацевтичному) закладах (фракультетах) післядипломної освіти» (із змінами, внесеними згідно 3 наказами МО3 України від 23.09.2003 р. № 447, від 24.04.2008 р. № 230, від 23.11.2009 р. № 856, від 31.12.2010 р. № 1179 та від 07.02.2012 р. № 90) визначає, що отримати фрах «Загальна практика - сімейна медицина» 
можуть педіатри та терапевти дільничні шляхом проходження навчання на циклі спеціалізації тривалістю 6 місяців (4 - очна частина і 2 - заочна). Решта лікарів, які закінчили інтернатуру за однією із спеціальностей лікувального або педіатричного профрілю, можуть пройти аналогічне навчання, але зі значно більшою тривалістю навчання (6 місяців - очна частина і 12 місяців - заочна).

Перепрофрілювання та респеціалізації лікарів інших спеціальностей здійснюються на 6-місячних циклах спеціалізації (типові навчальні плани і програми, затверджені МО3 України, 19952015 рр.). Вважаємо, що на цьому етапі така підготовка $€$ неефективною за браком часу.

Наказ МОЗ України від 19.09.1996 р. № 291 «Про затвердження Положення про спеціалізацію (інтернатуру) випускників вищих медичних і фрармацевтичних закладів освіти III-IV рівнів акредитації медичних фракультетів університетів» передбачав, що керівниками заочних баз стажування інтернів мають бути лише висококваліфіковані лікарі за фрахом «Загальна практика - сімейна медицина» I або вищої категорії, що забезпечувало б надання майбутнім сімейним лікарям можливість оволодіти всіма теоретичними аспектами та практичними навичками за обраним фрахом. Однак у більшості випадків спостерігаємо, що керівниками заочних баз стажування призначають лікарів інших спеціальностей (терапевти або педіатри), які не в змозі забезпечити надання та засвоєння всього необхідного переліку практичних навичок, передати специфіку спеціальності лікаря загальної практики - сімейної медицини та прищепити власний інтерес і любов до цієї профресії.

Зазначене свідчить про необхідність змін у підходах до підготовки медичних кадрів первинної ланки 3 акцентуванням пріоритетів не на кількісних, а на якісних показниках навчання, збільшенні термінів навчання на циклах інтернатури та спеціалізації з сімейної медицини за міжнародними стандартами, забезпеченні більш ретельного підходу до підбору професійних кадрів практичної охорони здоров'я, систематичному підвищенні їх безперервної кваліфрікації, зокрема на заочному етапі навчання. У зв'язку з цим, потребують перегляду навчальні плани та програми підготовки сімейних лікарів на циклах спеціалізації та інтернатури з фаху «Загальна практика - сімейна медицина» в плані терміну навчання, який повинен складати не менше трьох років, причому варто збільшити час навчання на відповідних кафедрах у вищих медичних закладах освіти за рахунок наскрізної програми в до- та післядипломний період навчання.

Підготовку сімейного лікаря необхідно починати 3 додипломної освіти 3 викладанням основ пропедевтики за синдромологічним підходом і формуванням психології та специфрічного клінічного мислення з орієнтацією на загальну практику - сімейну медицину і продовжувати на подальших етапах із розширенням і поглибленням знань, фрормуванням професійних навичок лікаря щодо діагностики та лікування певних захворювань в умовах первинної ланки.

Сьогодні підготовку майбутніх лікарів здійснюють за чинним типовим навчальним планом за спеціальностями «Лікувальна справа» та «Педіатрія», який лише на VI курсі навчання передбачає для обох спеціальностей вивчення дисципліни «Загальна практика - сімейна медицина». Програма навчальної дисципліни для студентів VI курсу «Загальна практика - сімейна медицина» включає один модуль ECTS, до складу якого входить 5 змістових модулів. Всього 90 годин/3 кредити (лекцій - 10, практичних занять - 40, СРС - 40).

На підготовку студентів принципам роботи сімейних лікарів в амбулаторно-поліклінічних закладах виділяють 216 годин. За цей час студенти повинні ознайомитись з методами роботи сімейного лікаря в умовах поліклініки та набути практичного досвіду. Під час практичних занять кожен студент опановує навички ведення обов'язкової документації сімейного лікаря, що затверджена наказом МО3 України від 28.03.2012 р. № 214: посімейний журнал дільниці сімейного лікаря (ф. 025-8-1/o), довідку для отримання путівки (ф. 070/o), санаторно-курортну карту (фр. 072/o), направлення на МСЕК (ф. 088/o), контрольну карту диспансерного нагляду (фр. 030/о) та багато інших.

У 2011 р. була затверджена Центральним методичним кабінетом МОЗ України «Наскрізна програма підготовки студентів медичних фракультетів ВМН3 та лікарів-інтернів для оволодіння практичними навичками та методиками, необхідними для роботи на посадах лікарів за спеціальністю «Загальна практика - сімейна медицина», яка передбачала навчання на IV-VI курсах та впродовж всього часу проходження інтернатури за фахом «Загальна практика - сімейна медицина» за такими дисциплінами: організація охорони здоров'я, внутрішні хвороби, дитячі хвороби, акушерство, гінекологія, репродуктологія та планування здорової сім'ї, хірургія, травматологія та ортопедія, урологія, онкологія, офтальмологія, оториноларингологія, стоматологія, нервові хвороби і нейрохірургія. У систему суміжних дисциплін включені питання психіатрії та протидії насильства в сім'ї, психологічні та фрізичні фрактори «булінгу». Варто в сучасних умовах епідемії кору в Україні включити питання боротьби 3 керованими інфекціями (інфекційні хвороби, дитячі інфекційні хвороби) та протидії туберкульозу (фртизіатрія), дерматовенерологію, реанімацію та інтенсивну терапію на догоспітальному етапі, фрізіотерапевтичне лікування. 
Основною метою інтернатури за спеціальністю «Загальна практика - сімейна медицина» $€$ формування професійної компетентності для забезпечення готовності лікарів-інтернів до самостійної роботи як лікаря-спеціаліста. Інтернатура проводиться у формі очно-заочного навчання на кафредрах вищих медичних навчальних закладів і закладів післядипломної освіти та практичного стажування в базових установах охорони здоров'я. Заочне стажування для лікарів-інтернів за спеціальністю «Загальна практика - сімейна медицина» повинно здійснюватись на базі первинної медико-санітарної допомоги та амбулаторій сімейного лікаря. Особливо важливим елементом навчального процесу є відпрацювання до автоматизму практичних навичок, особливо 3 надання першої невідкладної медичної допомоги. У Львівському національному медичному університеті імені Данила Галицького є досвід відпрацювання відповідних навичок, оскільки наприкінці 2016 р. був створений імітаційний центр із необхідними манекенами та франтомами. Подібні фантоми $€$ також на кафедрах акушерства, гінекології та перинатології, анестезіології та інтенсивної терапії, педіатрії та неонатології, сімейної медицини. Крім того, три року тому на базі Волинської обласної лікарні був відкритий навчально-тренувальний відділ, де лікарі-інтерни кафедр акушерства, гінекології та перинатології, анестезіології та інтенсивної терапії, педіатрії та неонатології, сімейної медицини, терапевтичної стоматології, хірургії та ендоскопії Волинської фрілії фракультету післядипломної освіти удосконалюють свою майстерність на відповідних манекенах та франтомах.

Навчальний план та програма інтернатури розраховані на 2 роки. Протягом першого року 6 місяців (936 год) - навчання на відповідних кафедрах вищих медичних навчальних закладів, 5 місяців (780 год) - робота на базі ПМСД та амбулаторій сімейного лікаря, один місяць - відпустка. Протягом другого року - 4 місяці (624 год) - навчання на відповідних кафедрах вищих медичних навчальних закладів, 7 місяців (1092 год) - робота на базі ПМСД та амбулаторій сімейного лікаря, один місяць - відпустка.

\section{Висновки}

Підготовка сімейного лікаря повинна починатись із додипломного етапу навчання із застосуванням досвіду європейської медицини, сучасних інноваційних комп'ютерних технологій, дистанційного навчання та новітніх досягнень педагогічної науки.

Вважаємо, що тривалість навчання в інтернатурі з сімейної медицини повинна відповідати рекомендованим термінам міжнародних професійних організацій: WONCA, EURACT, UEMO тощо і тривати не менше 3 років. Під час інтернатури обов'язково має бути ротація, з розподілом часу навчання - 50 \% в університетській клініці (госпіталях і закладах вторинного рівня медичної допомоги) та 50 \% - на амбулаторному рівні практики сімейного лікаря (база стажування). Причому заочне навчання має передбачати обов'язкове стажування тривалістю 1-3 місяці в тому закладі, куди скеровані майбутні спеціалісти відповідно до державного розподілу (місце першої праці). Забезпечувати процес навчання сімейних лікарів мають викладачі за фрахом «Загальна практика сімейна медицина» і спеціально підготовлені сімейні лікарі-тренери на базах стажування.

Перспективи подальших досліджень полягають у моніторингу та постійній популяризації галузі сімейної медицини з метою формування позитивної суспільної думки в населення.

\section{Список літератури}

1. Вороненко Ю. В. Підходи до підготовки сімейних лікарів в Україні та країнах Європи / Ю. В. Вороненко, О. Г. Шекера, В. І. Ткаченко // Український медичний часопис. - 2014. - № 3. - С. 116-120.

2. Глушко Л. В. Сучасні проблеми та перспективи підготовки сімейних лікарів на післядипломному етапі навчання /

л. В. Глушко, В. М. Кулаєць // Семейная медицина. - 2014. - № 5. - С. 141-143.

3. Навчальний план та уніфікована програма циклу спеціалізації за фрахом «Загальна практика-сімейна медицина» // МО3 України. - К., 2015. - 61 с.

4. Стрільчук Л. М. Якісна підготовка лікаря загальної практики - сімейної медицини - запорука успішності медичної ресрорми (огляд) / Л. М. Стрільчук, І. В. Шумлянський, Л. А. Ільницька // Практикуючий лікар. - 2015. - № 2. - С. $75-77$. 5. Типовий навчальний план і програма спеціалізації (інтернатури) випускників вищих медичних закладів освіти III-IV рівнів акредитації зі спеціальності «Загальна практика - сімейна медицина» // МОЗ України. - К., 2015. - 80 с. 6. Треумова C. I. Додипломна і післядипломна підготовка сімейних лікарів в Україні. Застосування сучасних дистанційних технологій у навчальному процесі / С. І. Треумова, Ю. М. Казаков, Є. Є. Петров // Семейная медицина. - 2015. - № 5. - C. 40-42.

\section{References}

1. Voronenko, Yu.V., Shekera, O.H., Tkachenko, V.I. (2014). Pidkhody do pidhotovky simeinykh likariv v Ukraini ta krainakh Yevropy [Approaches to the training of family doctors in Ukraine and European countries]. Ukrainskyi medychnyi chasopys - Ukrainian Medical Journal, 3, 116-120 [in Ukrainian].

2. Hlushko, L.V., \& Kulaiets, V.M. (2014). Suchasni problemy ta perspektyvy pidhotovky simeinykh likariv na pisliadyplomnomu etapi navchannia [Modern problems and perspectives of preparation of family doctors at the postgraduate stage of training]. Semeynaya meditsina - Family Medicine, 5, 141-143 [in Ukrainian]. 
3. Curriculum and unified program of specialization cycle on the field of "General Practice - Family Medicine" (2015). Ministry of Health of Ukraine. Kyiv [in Ukrainian].

4. Strilchuk, L.M., Shumlianskyi, I.V., \& Ilnytska, L.A. (2015). Yakisna pidhotovka likaria zahalnoi praktyky - simeinoi medytsyny - zaporuka uspishnosti medychnoi reform (ohliad) [Qualitative preparation of a general practitioner of family medicine is a guarantee of the success of medical reformy (review)]. Praktykuiychyi likar - Attending Doctor, 2, 75-77 [in Ukrainian].

5. (2015). Typovyi navchalnyi plan i prohrama spetsializatsii (internatury) vypusknykiv vyshchykh medychnykh zakladiv osvity III-IV rivniv akredytatsii zi spetsialnosti "Zahalna praktyka - simeina medytsyna" [Typical curriculum plan and program of specialization (internship) of graduates of higher medical educational institutions of III-IV levels of accreditation on specialty "General practice - family medicine"]. Ministry of Health of Ukraine [in Ukrainian].

6. Treumova, S.I., Kazakov, Yu.M., \& Petrov, Ye.Ye. (2015). Dodyplomna i pisliadyplomna pidhotovka simeinykh likariv v Ukraini. Zastosuvannia suchasnykh dystantsiinykh tekhnolohii u navchalnomu protsessi [Pre-graduate and postgraduate training of family doctors in Ukraine. Application of modern remote technologies in the educational process]. Semeynaya meditsina - Family Medicine, 5, 40-42 [in Ukrainian].

\title{
ГЛАВНЫЕ АСПЕКТЫ ПОДГОТОВКИ СЕМЕЙНОГО ВРАЧА В УКРАИНЕ
}

\section{О. Е. Сичкориз}

Львовский национальный медицинский университет имени Данила Галицкого, г. Львов, Украина

\begin{abstract}
Цель: анализ проблемы и перспективы подготовки семейных врачей на последипломном этапе.
Материалы и методы. Действующие законодательные акты проанализированы по принципу структурно-логического анализа.

Результаты. Основной целью интернатуры по специальности «Общая практика - семейная медицина» является фрормирование профессиональной компетентности для обеспечения готовности врачей-интернов к самостоятельной работе в качестве врача-специалиста. Интернатура проводится в форме очно-заочного обучения на кафедрах высших медицинских учебных заведений и заведений последипломного образования и практической стажировки в базовых учреждениях здравоохранения. Заочная стажировка для врачей-интернов по специальности «Общая практика - семейная медицина» должна осуществляться на базе первичной медико-санитарной помощи и амбулаторий семейного врача.

Учебный план и программа интернатуры рассчитаны на 2 года. В течение первого года - 6 месяцев обучение на соответствующих кафедрах высших медицинских учебных заведений, 5 месяцев - работа на базе первичной медико-санитарной помощи и амбулаторий семейного врача, один месяц - отпуск. В течение второго года - 4 месяца - обучение на соответствующих кафедрах высших медицинских учебных заведений, 7 месяцев - работа на базе первичной медико-санитарной помощи и амбулаторий семейного врача, один месяц - отпуск.

Подготовку семейного врача необходимо начинать с додипломного образования с преподаванием основ пропедевтики согласно синдромологического подхода и специфического клинического мышления с ориентацией на общую практику - семейную медицину.

Выводы. Продолжительность обучения в интернатуре по семейной медицине должна соответствовать рекомендованным терминам международных профессиональных организаций: WONCA, EURACT, UEMO и т. д. и продолжаться не менее 3 лет. Заочное обучение должно предусматривать обязательную стажировку продолжительностью 1-3 месяца в том заведении, куда направлены будущие специалисты по государственному распределению.
\end{abstract}

КЛЮЧЕВЫЕ СЛОВА: семейный врач; подготовка; первичная медико-санитарная помощь.

\section{THE MAIN ASPECTS OF TRAINING OF A FAMILY DOCTOR IN UKRAINE}

\author{
O. Y. Sichkoriz
}

Danylo Halytskyi Lviv National Medical University, Lviv, Ukraine

Purpose: to analyze the problem and prospects of training of family doctors at the postgraduate stage.

Materials and Methods. The current legislative acts are analyzed by the principle of structural and logical analysis.

Results. The main purpose of internship on specialty of General Practice - Family Medicine is the formation of professional competence for the readiness of doctors-interns to work independently as doctors-specialists. Internship is conducted in the form of full-time and part-time studies at the departments of higher medical educational institutions and postgraduate educational institutions and practical internships in basic health care institutions. Part-time internship for doctors-interns on specialty of General Practice - Family Medicine should be carried out at the bases of primary medical and sanitary care and ambulatory of the family doctor.

The curriculum plan and program of internship on specialty of Family Medicine are designed for 2 years. During the first year - 6 months - training at the relevant departments of higher medical educational institutions, 
5 months - work in PMSC/ambulatories of family doctor, 1 month - vacation. During the second year -4 months training at the relevant departments of higher medical educational institutions, 7 months - work in PMSC/ ambulatories of family doctor, 1 month - vacation.

The training of the family doctor should begin with pre-graduate education with the teaching of the principles of propedeutics according to the syndromological approach and specific clinical thinking with an orientation towards general practice - family medicine.

Conclusions. The duration of study in internship of Family Medicine have to correspond to the recommended terms of international professional organizations: WONCA, EURACT, UEMO etc., and last for at least 3 years. Part-time training should include compulsory internship for a period of 1-3 months in the institution where future specialists are directed according to the state distribution.

KEY WORDS: family doctor; training; primary medical and sanitary care.

Рукопис надійшов до редакції 30.11.2018 p.

\section{Відомості про автора:}

Січкоріз Орест Євгенович - кандидат медичних наук, доцент кафедри дитячих інфекційних хвороб, декан фракультету післядипломної освіти Львівського національного медичного університету імені Данила Галицького; тел.: +38(032) 276-93-74; +38(050) 317-15-54. 